\title{
Selection and processing of large suspended algae in the oyster Crassostrea gigas
}

\author{
Bruno Cognie $^{1, *}$, Laurent Barillé ${ }^{1}$, Guillaume Massé $^{2}$, Peter G. Beninger ${ }^{1}$ \\ ${ }^{1}$ Isomer, Faculté des Sciences, Université de Nantes, 44322 Nantes, Cedex 03, France \\ ${ }^{2}$ Department of Environmental Sciences, University of Plymouth, Drake Circus, Plymouth PL4 8AA, United Kingdom
}

\begin{abstract}
The mechanisms and sites of processing and selection of large natural algal particles were studied in the oyster Crassostrea gigas, which possesses a heterorhabdic pseudolamellibranch gill type. Endoscopic observations of processing $1000 \mathrm{cells} \mathrm{m}^{-1}$ suspensions of the pennate diatoms Pleurosigma planctonicum and Rhizosolenia setigera were performed, as well as endoscope-directed sampling of 100 cells ml ${ }^{-1}$ mixed suspensions of intact $(25 \%)$ and empty $(75 \%) 150 \times 200 \mu \mathrm{m}$ Coscinodiscus perforatus. Video endoscopy was used to observe processing on the gill and to allow in vivo sampling of contents of the dorsal and ventral particle tracts, while pseudofaeces was collected from the individual flow-through chambers. Selection indices were calculated for empty C. perforatus at each processing site. Only those $P$. planctonicum orientated in a dorso-ventral position could enter the principal filaments (PF) for delivery to the dorsal acceptance tract. $R$. setigera almost never entered the PF, being prevented by its curved and twisted shape. Visual counts of intact versus empty C. perforatus were done on samples from the ambient medium, ventral and dorsal particle tracts, and pseudofaeces. They showed that the percentages of intact and empty cells in both the dorsal and ventral particle tracts were identical to those initially presented (Kruskal-Wallis test; $\mathrm{p}>0.05$ ). In contrast, the pseudofaeces contained over $98 \%$ empty cells (Kruskal-Wallis test; $\mathrm{p} \leq 0.001$, degree of selection ranged from +29 to $+34 \%$ ). These results show that (1) large natural particles within the size range naturally encountered by $C$. gigas may only be subjected to qualitative selection on the gills if their shape and dimension allow them to enter the PF, and (2) the site of selection for particles unable to enter the PF is not the gill, but rather the labial palps. Selection sites and mechanisms in heterorhabdic bivalves should therefore be studied over the entire range of naturally available particle sizes. Given the periodic dominance of large diatoms in coastal temperate waters, the labial palp processing site could be of considerable importance in the dynamics of seston flow in oysterdominated ecosystems.
\end{abstract}

KEY WORDS: Crassostrea gigas $\cdot$ Selection sites $\cdot$ Large diatoms $\cdot$ Endoscopy

\section{INTRODUCTION}

The Bivalvia comprise a large group of ubiquitous suspension-feeders, in both marine and freshwater habitats. Their trophic activity is an important determinant of seston and biosediment dynamics in these ecosystems (Bayne \& Hawkins 1992, Dame 1993, Bayne 1998, Soto \& Mena 1999, Budd et al. 2001). Clearance and filtration-rate studies have shown that suspension-feeding on relatively small particles (generally $<1 \mathrm{~mm}$ ) requires the processing of large num- bers of particles per second (Bayne et al. 1988, 1993, Barillé et al. 1997, Navarro \& Widdows 1997, Bacon et al. 1998), whereas the nutritional quality of seston particles may be extremely heterogeneous, including many non-nutritive or even toxic particles. The ability of bivalves to selectively ingest certain particles from mixtures has been extensively documented (Newell \& Jordan 1983, Peirson 1983, Shumway et al. 1985, 1990, Prins et al. 1991, Bougrier et al. 1997). The few studies using algal species significantly present in the natural habitat of the specimens studied have also demon- 
strated particle selection (Miura \& Yamashiro 1990, Cognie et al. 2001). Despite considerable recent progress on the basic components of particle processing mechanisms, i.e. capture (Silverman et al. 1996, 1999), transport and ingestion volume regulation (Beninger et al. 1992, 1997a,b, Ward et al. 1993, 1994, Beninger \& St-Jean 1997a), and pseudofaeces evacuation (Beninger \& Veniot 1999, Beninger et al. 1999), the exact sites and mechanisms of particle selection have remained largely obscure.

As has been proposed by several authors (e.g. Atkins 1937, Beninger \& St-Jean 1997b), the fundamental anatomical differentiation of the filaments composing the bivalve heterorhabdic gill (principal, $\mathrm{PF}$, and ordinary, OF), together with the oppositely directed particle trajectories on these 2 filament types, would appear to constitute a probable basis for particle selection at the gill in bivalves possessing such a gill type. Using endoscope-directed in vivo sampling, selection at the gill has recently been demonstrated in oysters (Ward et al. 1998), which possess the most complex heterorhabdic gill (partial tissue fusion, with both dorsal and ventral particle grooves). These authors did not observe evidence of particle selection at the labial palps, but did not exclude the possibility of such processing under undetermined circumstances.

Although suspension-feeding bivalves are microphagous by their very nature, at the microscopic level there is nonetheless a great size range of seston particles which may be ingested. While the capture efficiency of most species (those which possess welldeveloped latero-frontal cirri, i.e. homorhabdic species such as mussels) ranges from 50 to $100 \%$ for particles from 1 to 4 m (Haven \& Morales-Alamo 1970, Møhlenberg \& Riisgård 1978, Wright et al. 1982, Silverman et al. 1995, Newell \& Langdon 1996, Nakamura 2001), heterorhabdic bivalves, including oysters (Fam. Ostreidae) and scallops (Fam. Pectinidae), most efficiently capture particles from 4 to $5 \mu \mathrm{m}$ (Møhlenberg \& Riisgård 1978, Riisgård 1988). The recent demonstration of particle selection at the gill in oysters (Ward et al. 1998) focused on particles close to the lower limit of this size range (3 to $20 \mu \mathrm{m}$ ), which were preferentially directed to the PF and thence to the dorsal particle tract. Many planktonic algal species, however, including the marine temperate dominant diatoms Coscinodiscus spp., often present considerably larger sizes $(>100 \mu \mathrm{m})$ than those used in this study. The relatively narrow opening of the PF in oysters (approx. $70 \mu \mathrm{m}$, see Fig. 2A), and the anatomical impossibility of expansion of this opening (due to tissue fusion), should in fact impose a critical size threshold (CST) for the entry and transport of many otherwise appropriate algal species. The entry of algal cells which present at least 1 axis larger than the PF opening would therefore be problematic, whereas entry to and transport in the PF should be impossible for algal cells which present no axis small enough to enter the $\mathrm{PF}$, such as the larger Coscinodiscus spp. Selection at the oyster gill would thus seem compromised or even impossible for particles above the CST of $70 \mu \mathrm{m}$.

In this study we document for the first time the processing of large, naturally occurring algal particles, and examine the features of selection and determine the selection sites for seston particles larger than the CST in the oyster Crassostrea gigas, using endoscopic observation of the processing of a benthic and a planktonic pennate diatom (1 axis > CST), as well as endoscope-directed sampling during the processing of the central diatom Coscinodiscus perforatus (all axes > CST).

\section{MATERIALS AND METHODS}

Selection of algal species. Diatoms were chosen as the algal group for this study due to the presence of essentially incompressible frustules, whose dimensions would not be subject to change during capture and processing. For observations of particle processing in algae with 1 axis > CST, the pennate diatoms Pleurosigma planctonicum and Rhizosolenia setigera were chosen; both are naturally occurring temperate diatoms, and although $P$. planctonicum is considered benthic, it is often found resuspended in the plankton, as was the case in the present study. Moreover, these 2 species have been frequently observed in oyster stomach contents (Leroux 1956, Paulmier 1972).

For observations, in vivo sampling, and quantitative data concerning particle processing and selection in algae with all axes $>$ CST, the central diatom Coscinodiscus perforatus was chosen. As the dominant temperate nearshore planktonic diatom genus (Levinton 1982, Lakshminayarana 1983, Barnes \& Hughes 1988), Coscinodiscus spp. are likely to constitute a significant fraction of the planktonic particles encountered by coastal suspension-feeders; indeed, they have been observed in great abundance in oyster stomach contents (Leroux 1956, Paulmier 1972, M. Bricelj pers. comm.). In order to present particles which differed with respect to their trophic value but not their size or shape, we used both intact cells and cleaned, empty frustules.

Algal cultures. Pleurosigma planctonicum and Coscinodiscus perforatus (identified using scanning electron microscopy, Fig. 1) were sampled in June 2000 using a $75 \mu \mathrm{m}$ plankton net from a pier at Le Croisic port $\left(2^{\circ} 32^{\prime} \mathrm{W}, 47^{\circ} 18^{\prime} \mathrm{N}\right)$. Each species was isolated from the sample using an inverted microscope and micropipette, 1 cell at a time, using Guillard F/2 medium (Guillard 1982), at $14^{\circ} \mathrm{C}$ and salinity 28 , with a $14 \mathrm{~h}$ photoperiod. 

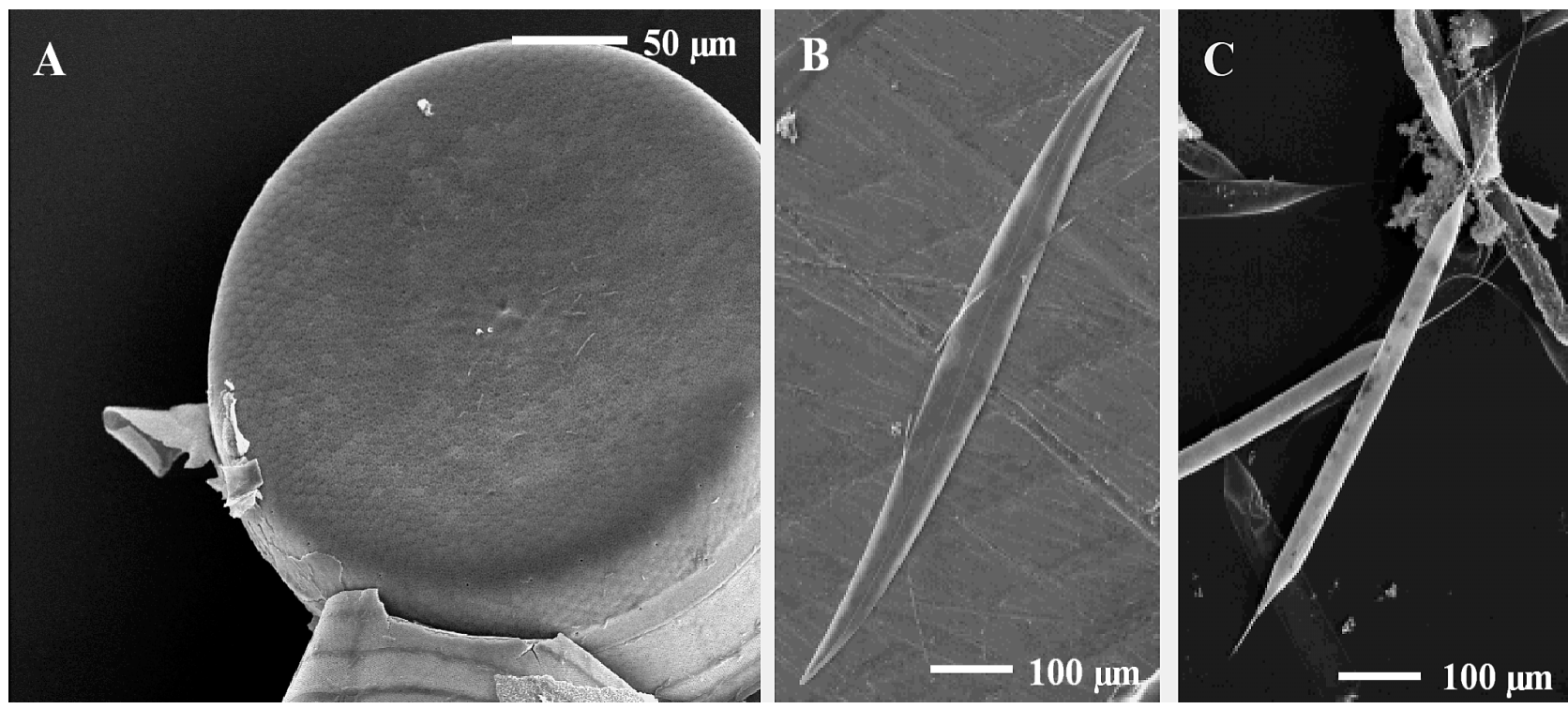

Fig. 1. The 3 microalgae species used for endoscopic observations. (A) Coscinodiscus perforatus; (B) Pleurosigma planctonicum; (C) Rhyzosolenia setigera

Experimental 201 cultures were obtained in the same conditions using the same medium. Twenty litre cultures of Rhizosolenia setigera (Fig. 1) were obtained in the same manner, from the CCMP 1820 strain furnished by the Provasoli-Guillard National Center for Culture of Marine Phytoplankton, McKown Point, West Boothbay Harbour, Maine, USA.

The dimensions of the 3 algal species are shown in Table 1; Pleurosigma planctonicum presented 1 axis larger than the oyster PF (approx. $70 \mu \mathrm{m}$ ), while both axes of Coscinodiscus perforatus were larger than the oyster PF. The curved and twisted shape of Rhizosolenia setigera presented axes which were larger than the oyster PF in all dimensions.

Coscinodiscus perforatus empty:intact mixture preparation. The experimental mixtures of empty (75\%) and intact ( $25 \%$ ) C. perforatus were obtained by adding empty cells from senescent cultures to early stationaryphase cultures. Empty cells from the senescent cul-

Table 1. Key characteristics of the 3 microalgae species and oysters used for endoscopic observations. L: valve length, W: valve width, D: valve diameter, A: pervalvar axis, PFW: principal filament width (oyster). Mean sizes are given with their $95 \%$ confidence interval $(n=30)$

\begin{tabular}{|lcc|}
\hline Species & Size $(\mu \mathrm{m})$ & Ecological type \\
\hline Coscinodiscus perforatus & D: $250 \pm 2.5$, A: $150 \pm 1.9$ & Pelagic \\
$\begin{array}{l}\text { Pleurosigma planctonicum } \\
\text { Rhizosolenia setigera }\end{array}$ & L: $350 \pm 3$, W: $35 \pm 0.2$ & Benthic \\
$\begin{array}{l}\text { (CCMP 1820) } \\
\text { Crassostrea gigas }\end{array}$ & PFW: $69 \pm 0.9$ & Benthic suspension-feeder \\
\hline
\end{tabular}

tures were washed with hydrogen peroxide solution to remove residual organic matter, and rinsed several times with filtered seawater. The empty cells therefore differed from the intact cells only in their absence of organic matter. The final mixture thus contained empty cells from both the senescent cultures (the vast majority) and from the few naturally occurring dead cells of the stationary-phase cultures.

Specimen preparation. The oysters used in the present study were wild individuals from Bourgneuf Bay (mean shell length $15 \mathrm{~cm}$ ). Shell epibionts were removed manually, and the specimens were placed in a sodium hypochlorite solution for $2 \mathrm{~min}$ in order to eliminate shell borers such as Polydora sp. The cleaned individuals were then rinsed several times and maintained in aquaria using oxygenated filtered seawater. Specimens were fed with various cultured algae during stabilisation, and starved for $24 \mathrm{~h}$ prior to endoscopic observations, in order to establish basal conditions for the gut and to avoid ambient water contamination via the faeces.

Due to the hermetic seal of the oyster valves when manipulated, it was necessary to drill a small aperture for entry of the endoscope optical insertion tube (OIT), taking care not to damage the mantle edge. Although observations were only performed when the shells were opened and the oyster actively filtering, the aperture prevented breakage of the OIT when the valves closed periodically. Speci- 
mens were used for observation at least $24 \mathrm{~h}$ following this operation.

Endoscopic observations. Endoscopy was performed according to the general procedure of Ward et al. (1991) and Beninger et al. (1992). Rather than the standard $1.7 \mathrm{~mm}$ OIT, a $4 \mathrm{~mm}$ OIT was used. While less manoeuvrable in the pallial cavity, superior resolution is obtained from larger OIT diameters; our manoeuvrability requirements were largely limited to ventraldorsal displacement, in order to visualize the dorsal arch and the ventral bend. The OIT was attached to a colour camera (Sony Hyper HAD, CCD-IRIS/RGB) via an optical adapter. The camera was attached to a micromanipulator, enabling displacement of the OIT. Video images were recorded directly in digital format using a computer equipped with a video card (miroVIDEO DC 1000, Pinnacle Systems) and with Adobe Premier 5.0 software. Specimens were placed in 31 chambers with open-circuit seawater flow. Algae were added to the experimental chambers to obtain a final concentration of 100 cells $\times \mathrm{ml}^{-1}$; this concentration was verified using microscopic counts of $5 \mathrm{ml}$ aliquots, and maintained throughout the observation period. Although the particle concentrations used in the present study were somewhat low (due to the difficulty of obtaining high densities of these naturally occurring species under culture conditions), the large cell sizes compensated in terms of available biomass (approx. $8 \mathrm{mg} \mathrm{l}^{-1}$ ). Visual rather than automated counts were performed in order to distinguish intact from empty Coscinodiscus perforatus cells, using the technique of Utermöhl (1958).

Sampling of processed particles was performed using a micropipette in the dorsal arch and ventral particle groove (Fig. 2B). Pseudofaeces was also recovered using a micropipette at the end of each observation period. The percentages of empty and intact cells were determined via visual counts for the ambient water, the dorsal and ventral particle grooves, and the pseudofaeces. These percentages were compared using the Kruskal-Wallis test, which is well-adapted for use in a contingency table, where the rows represent ordered categories (intact and empty cells) and the columns represent the different populations (sampling sites; Conover 1999). The following null hypothesis was advanced:

$H_{0}$ : \% (empty:intact) $=75: 25$ in pseudofaeces and at all sites of particle processing. In this case, no selection would have been performed by the pallial organs.

Several alternative experimental hypotheses were also advanced:

$H_{1}$ : \% (empty:intact) different in pseudofaeces and at various sites of particle processing. In this case, selection would have been performed by the pallial organs.

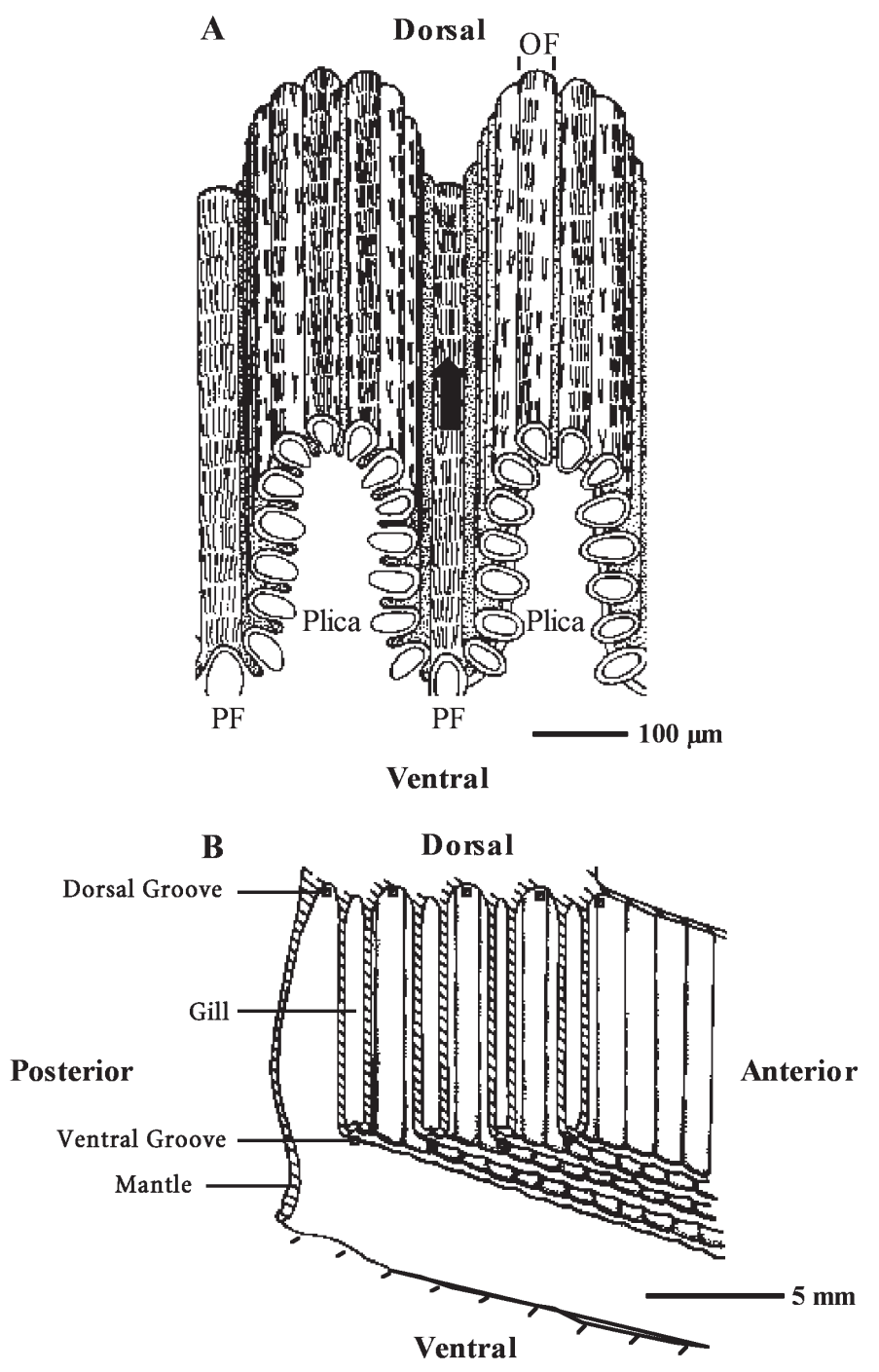

Fig. 2. Crassostrea gigas. (A) Stereodrawing of 2 gill plicae. Black arrow indicates movement of particles in the principal filament (PF) rejection tract. (B) Transverse section through the gills showing in vivo sampling sites (dorsal and ventral groove)

$H_{2}$ : \% (empty:intact) $=75: 25$ in gill particle grooves.

In this case, selection is not performed by the gills, and any observed enrichment in empty frustules in the pseudofaeces is therefore due to the labial palps.

A selection index (SI) was calculated for the various pallial sites (dorsal and ventral gill tracts, labial palps) in order to express the degree and direction of selection at each site:

$$
\mathrm{SI}=\left(\left[S_{\%}-W_{\%}\right] / W_{\%}\right) \times 100
$$

where $W_{\%}$ is the percentage of empty Coscinodiscus perforatus cells in the water and $S_{\%}$ the percentage of empty C. perforatus cells in the sample (ventral or dorsal grooves, pseudofaeces). 


\section{RESULTS}

\section{Qualitative observations}

Observations of Pleurosigma planctonicum showed that this species was often transported ventrally across several filaments of the plicae, in various orientations (Fig. 3A,B). These cells could only enter the PF if they were orientated in a perfect dorso-ventral manner. The larger, curved and twisted Rhizosolenia setigera cells, however, were never observed entering the PF, nor exiting them in the dorsal particle groove. This species appeared to be transported only ventrally, in various orientations, often straddling the gill plicae and their associated PF (Fig. 3C,D).

As was expected from the size of Coscinodiscus perforatus in all 3 dimensions, none of these cells were ever observed entering the PF (Fig. 3E,F). Both empty and intact cells followed the same trajectories, along the gill plicae to the ventral particle groove. On very rare occasions, extremely small numbers of both types of cells were observed in the dorsal particle groove.

\section{Quantitative observations-Coscinodiscus perforatus}

The value of the test statistic $T$ obtained in the Kruskal-Wallis test clearly leads to rejection of the null hypothesis $H_{0}$ and acceptance of $H_{1}$ : selection occurred on the pallial organs (Kruskal-Wallis test; $T=115.124, \mathrm{df}=2, \mathrm{p}<0.001)$. Because $H_{0}$ was rejected, the a posteriori multiple comparisons procedure could be used and showed that there was no significant difference between the percentages of empty versus intact cells in either the ambient medium, the dorsal or the ventral particle grooves (Fig. 4; Kruskal-Wallis test, $\mathrm{p} \geq 0.05$ ), thus allowing acceptance of $\mathrm{H}_{2}$ : no selection occurred on the gill. There was a significant difference between the empty:intact percentages of the pseudofaeces and the other sampling sites (Kruskal-Wallis test, $\mathrm{p}<0.001$; pseudofaeces empty:intact $>>75: 25$ ): the selection observed in favour of the ingestion of these large cells was performed by the labial palps.

The selection index clearly showed the effect of selection at the labial palps: values ranged from +29 to $+34 \%$ in the pseudofaeces, versus nearly zero at all other sampling sites. Given that the initial mixture already contained $75 \%$ of empty cells, this degree of selection produced pseudofaeces almost totally composed of empty cells (approx. 98\%).

\section{DISCUSSION}

The qualitative endoscopic observations of Pleurosigma planctonicum showed that entry to the PF and subsequent dorsal (acceptance) tract was only possible if the algal cell could be positioned in a perfect dorsoventral manner. Many cells travelling ventrally along the plicae could not be positioned in this way prior to being incorporated in the ventral particle groove. Selection at the gill for this algal species can therefore be expected to be incomplete, depending on how many cells are correctly positioned.

In the case of Rhizosolenia setigera, entry to the PF was compromised not only along the length axis, but also in the other 2 axes, due to its curved and twisted shape. In the case of this species, therefore, selection is impossible on the Crassostrea gigas gill. Therefore, the qualitative observations of particle processing using Pleurosigma planctonicum and $R$. setigera both point to the importance of particle dimension (in all axes) for the operation of selection at the oyster gill.

The proportional equality of the empty:intact Coscinodiscus perforatus cells at all processing sites, except the pseudofaeces in the oyster Crassostrea gigas, leads to the rejection of the null hypothesis $H_{0}$ (no selection at any site), and the acceptance of both experimental hypotheses: selection does occur for these naturally occurring large particles, and the site is not the gill, but rather the labial palps. The labial palps are thus established as the selection sites for particles > CST in this heterorhabdic pseudolamellibranch processing system.

The family Ostreidae presents the most complex bivalve gill system (heterorhabdic pseudolamellibranch gills, with both a dorsal and a ventral semienclosed particle tract). The results of the present study show that, although it may contain high percentages of rejecta, the ventral tract can nonetheless efficiently transport particles to the palps for further selection. It therefore should not be considered a 'rejection' tract, as might be concluded from the study of Ward et al. (1998).

Taken together, the results of Ward et al. (1998), who failed to find evidence of selection by the palps in the oysters Crassostrea virginica and $C$. gigas using small particles $(\ll \mathrm{CST})$, and those of the present study, which demonstrate selection by the labial palps in the oyster C. gigas when larger (>CST) particles are used, point to a coherent paradigm: the oyster gill can perform particle selection for small particles, but for particles too large to enter the PF, no selection is possible at the gill. Selection for larger particles does occur, however, and the unique site of selection concerning larger particles is the labial palps. Although Ward et al. (1998) did not exclude the possibility of palp particle selection under particle regimes more complex than the one they used (Rhodomonas lens + Spartina alterniflora detritus), we show here that such selection can occur in the simplest of particle regimes: intact and empty cells of the same diatom species. Selection 


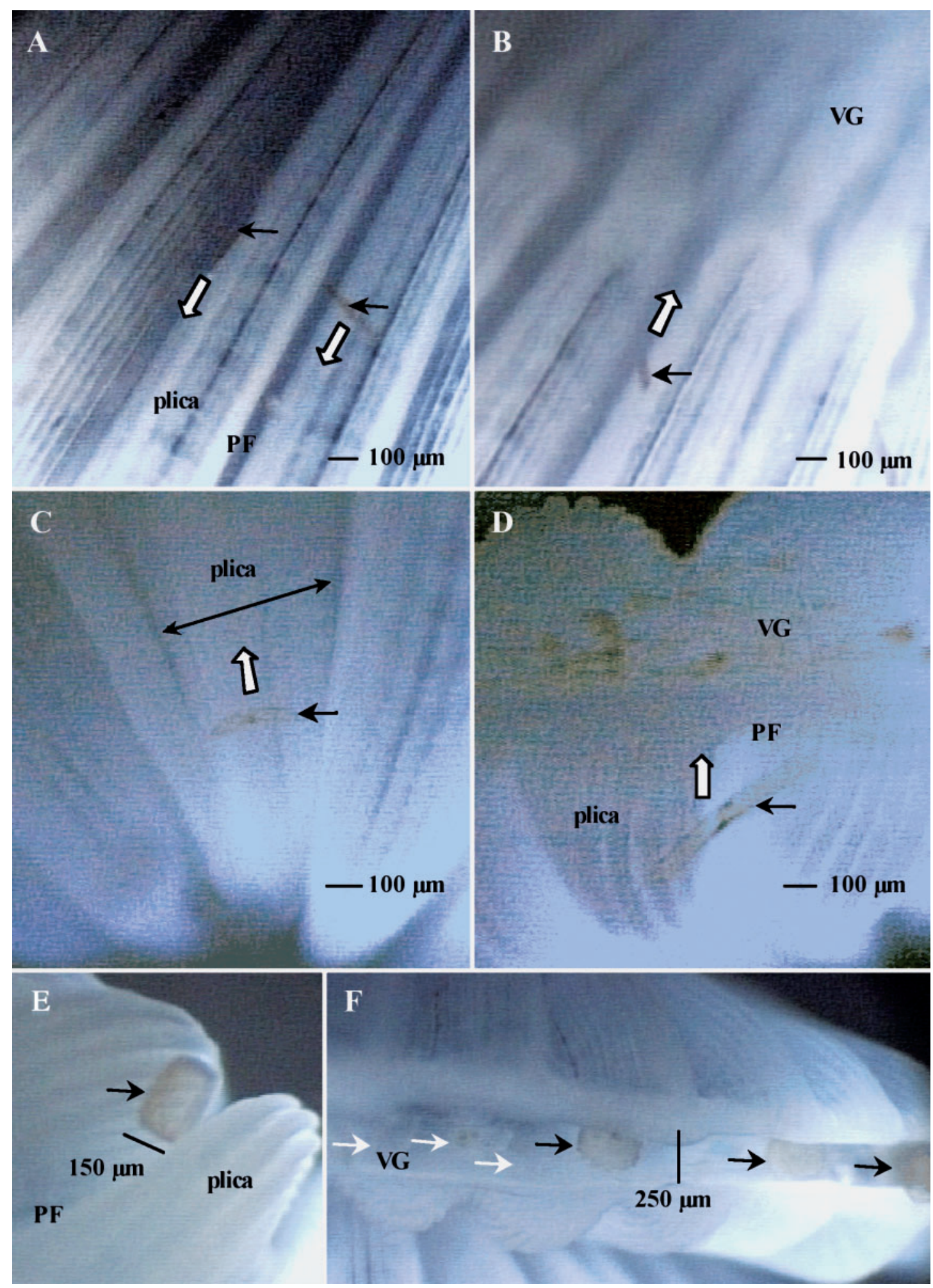

Fig. 3. Crassostrea gigas. Endoscope video images showing, in vivo, diatom cells processed on the gill. Movement is indicated by thick white arrows. PF: principal filament, VG: ventral groove. (A) Pleurosigma planctonicum cells (black arrows) transported ventrally across several filaments of the plicae; (B) P. planctonicum cell (black arrow) entering a PF orientated in a perfect dorsoventral manner; (C, D) Rhizosolenia setigera cells (black arrows) transported ventrally across gill plicae; (E) Coscinodiscus perforatus. Intact cell (black arrow) transported along the gill plicae to the ventral particle groove; (F) C. perforatus. Empty (white arrows) and intact (black arrows) in the ventral particle groove 


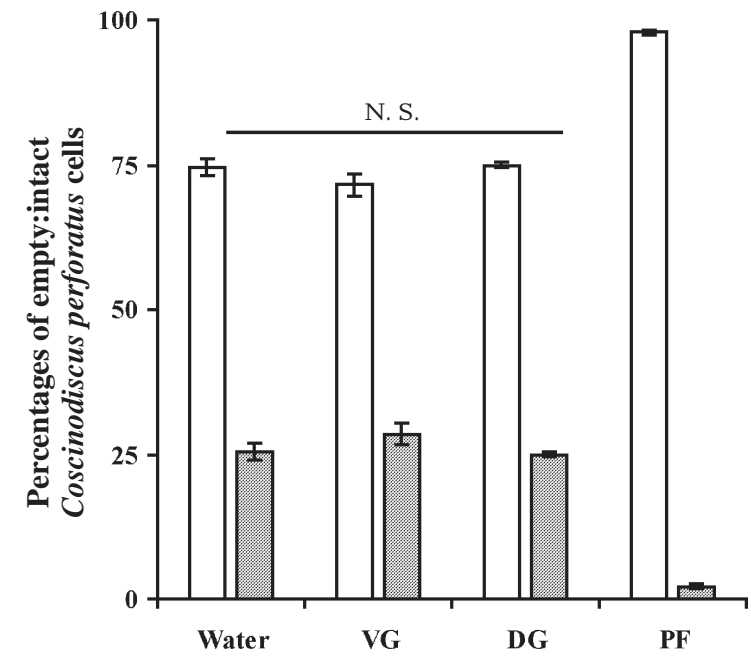

Fig. 4. Coscinodiscus perforatus. Percentages of empty:intact cells in water, ventral and dorsal grooves, and pseudofaeces. Percentages are given with their range. N.S.: not significant

under mixed regimes of a wide size range is thus necessarily a 2 -stage and 2 -site process, with selection at the gill for particles $<\mathrm{CST}$, and selection at the palps for particles >CST. It is thus evident that both gills and palps play roles in qualitative particle selection in oysters, and that particle size is a determinant of the localization of the selection site.

The labial palps of bivalves participate not only in particle selection, but also in ingestion volume regulation (Foster-Smith 1978, Beninger et al. 1997a). In bivalves that inhabit turbid waters (such as oysters), the importance of the palps in particle processing is demonstrated by the correlation between turbidity and palp size (Theisen 1982, Barillé et al. 2000).

In temperate and boreal inshore waters, the naturally occurring phytoplankton assemblages are dominated by diatoms such as those used in the present study (Levinton 1982, Lakshminarayana 1983, Barnes \& Hughes 1988), most of which start their population cycle at their largest size. Large algal particles may therefore be numerically dominant in the available seston, underscoring the importance of the labial palp selection site in oyster species. On a population scale, the handling capacity of this selection/ ingestion volume regulation site may be an important determinant in the seston dynamics of coastal and estuarine habitats which possess significant oyster reefs.

Acknowledgements. The authors wish to thank the Syndicat Mixte pour le Développement de l'Aquaculture et de la Pêche for their financial support during this work.

\section{LITERATURE CITED}

Atkins D (1937) On the ciliary mechanisms and interrelationships of lamellibranches. Part II. Sorting devices on the gills. Q J Microsc Sci 79:339-373

Bacon GS, MacDonald BA, Ward JE (1998) Physiological responses of infaunal (Mya arenaria) and epifaunal (Placopecten magellanicus) bivalves to variations in the concentration and quality of suspended particles. I. Feeding activity and selection. J Exp Mar Biol Ecol 219:105-125

Barillé L, Prou J, Héral M, Razet D (1997) Effects of high natural seston concentrations on the feeding, selection, and absorption of the oyster Crassostrea gigas (Thunberg). J Exp Mar Biol Ecol 212:149-172

Barillé L, Haure J, Cognie B, Leroy A (2000) Variations in pallial organs and eulatero-frontal cirri in response to high particulate matter concentrations in the oyster Crassostrea gigas. Can J Fish Aquat Sci 57(4):837-843

Barnes RSK, Hughes RN (1988) An introduction to marine ecology, 2nd edn. Blackwell Scientific Publications, Oxford

Bayne BL (1998) The physiology of suspension feeding by bivalve molluscs: an introduction to the Plymouth 'TROPHEE' workshop. J Exp Mar Biol Ecol 219:1-19

Bayne BL, Hawkins AJS (1992) Ecological and physiological aspects of herbivory in benthic suspension-feeding molluscs. In: Hawkins JDM, Price SJ (eds) Plant-animal interactions in the marine benthos. Systematics Association, Special Volume No. 46. Clarendon Press, Oxford, p 265-288

Bayne BL, Hawkins AJS, Navarro E (1988) Feeding and digestion in suspension-feeding bivalve molluscs: the relevance of physiological compensations. Am Zool 28:147-159

Bayne BL, Iglesias JIP, Hawkins AJS, Navarro E, Héral M, Deslous-Paoli JM (1993) Feeding behaviour of the mussel Mytilus edulis: responses to variations in quantity and organic content of the seston. J Mar Biol Assoc UK 73:813-829

Beninger PG, St-Jean SD (1997a) The role of mucus in particle processing by suspension-feeding marine bivalves: unifying principles. Mar Biol 129:389-397

Beninger PG, St-Jean SD (1997b) Particle processing on the labial palps of Mytilus edulis and Placopecten magellanicus (Mollusca: Bivalvia). Mar Ecol Prog Ser 147:117-127

Beninger PG, Veniot A (1999) The oyster proves the rule: mechanisms of pseudofaeces transport and rejection on the mantle of Crassostrea virginica and C. gigas. Mar Ecol Prog Ser 190:179-188

Beninger PG, Ward JE, MacDonald BA, Thompson RJ (1992) Gill function and particle transport in Placopecten magellanicus (Mollusca: Bivalvia) as revealed using video endoscopy. Mar Biol 114:281-288

Beninger PG, Dufour SC, Bourque J (1997a) Particle processing mechanisms of the eulamellibranch bivalves Spisula solidissima and Mya arenaria. Mar Ecol Prog Ser 150: 157-169

Beninger PG, Lynn JW, Dietz TH, Silverman H (1997b) Mucociliary transport in living tissue: the two-layer model confirmed in the mussel Mytilus edulis L. Biol Bull 193:4-7

Beninger PG, Veniot A, Poussart Y (1999) Principles of pseudofaeces rejection on the bivalve mantle: integration in particle processing. Mar Ecol Prog Ser 178:259-269

Bougrier S, Hawkins AJS, Héral M (1997) Preingestive selection of different microalgal mixtures in Crassostrea gigas and Mytilus edulis, analyzed by flow cytometry. Aquaculture 150:123-134

Budd JW, Drummer TD, Nalepa TF, Fahnenstiel GL (2001) Remote sensing of biotic effects: Zebra mussels (Dreissena polymorpha) influence on water clarity in Saginaw Bay, Lake Huron. Limnol Oceanogr 46(2):213-223 
Cognie B, Barillé L, Rincé Y (2001) Selective feeding of the oyster Crassostrea gigas fed on a natural microphytobenthos assemblage. Estuaries 24(1):126-131

Conover WJ (1999) Practical nonparametric statistics, 3rd edn. J Wiley \& Sons, New York

Dame RF (1993) Bivalve filter-feeders in estuarine and coastal ecosystem processes. NATO ASI Series, Vol G 33. Springer-Verlag, Berlin

Foster-Smith RL (1978) The function of the pallial organs of bivalves in controlling ingestion. J Molluscan Stud 44: 83-99

Guillard RRL (1982) Culture of phytoplankton for feeding marine invertebrates. In: Smith WL, Chanley MH (eds) Culture of marine invertebrates animals. Plenum Press, New York, p 108-132

Haven DS, Morales-Alamo R (1970) Filtration of particles from suspensions by the American oyster Crassostrea virginica. Biol Bull (Woods Hole) 139:248-264

Lakshminarayana JSS (1983) Phytoplankton of the Quoddy Region. In: Thomas MLH (ed) Marine and coastal systems of the Quoddy Region, New Brunswick. Can Spec Publ Fish Aquat Sci 64, p 176-192

Leroux S (1956) Phytoplancton et contenus stomacaux d'huîtres portugaises (Gryphea angulata Lmk) dans le bassin d'Arcachon. Rev Trav Inst Pêches Marit 20(2): $163-170$

Levinton JS (1982) Marine ecology. Prentice-Hall, Englewood Cliffs, NJ

Miura T, Yamashiro T (1990) Size selective feeding of Anodonta calipygos, a phytoplanktivorous freshwater bivalve, and viability of egested algae. Jpn J Limnol 51(2):73-78

Møhlenberg F, Riisgård HU (1978) Efficiency of particle retention in 13 species of suspension feeding bivalves. Ophelia 17:239-246

Nakamura Y (2001) Filtration rates of the Manila clam, Ruditapes philippinarum: dependence on prey items including bacteria and picocyanobacteria. J Exp Mar Biol Ecol 266: 181-192

Navarro JM, Widdows J (1997) Feeding physiology of Cerastoderma edule in response to a wide range of seston concentrations. Mar Ecol Prog Ser 152:175-186

Newell RIE, Jordan SJ (1983) Preferential ingestion of organic material by the American oyster Crassostrea virginica. Mar Ecol Prog Ser 13:47-53

Newell RIE, Langdon CJ (1996) Mechanisms and physiology of larval and adult feeding. In: Kennedy VS, Newell RIE, Eble AF (eds) The Eastern oyster Crassostrea virginica. Maryland Sea Grant College, Maryland, p 185-229

Paulmier G (1972) Seston, phytoplancton et microphytobenthos en rivière d'Auray. Leur rôle dans le cycle biologique des huîtres (Ostrea edulis L.). Rev Trav Inst Pêches Marit 36:373-506

Peirson WN (1983) Utilization of eight algal species by the bay

Editorial responsibility: Otto Kinne (Editor), Oldendorf/Luhe, Germany scallop, Argopecten irradians concentricus (Say). J Exp Mar Biol Ecol 68:1-11

Prins TC, Smaal AC, Pouwer AJ (1991) Selective ingestion of phytoplankton by the bivalves Mytilus edulis L. and Cerastoderma edule (L.). Hydrobiol Bull 25:93-100

Riisgård HU (1988) Efficiency of particle retention and filtration rate in 6 species of Northeast American bivalves. Mar Ecol Prog Ser 45:217-223

Shumway SE, Cucci TL, Newell RC, Yentsch CM (1985) Particle selection, ingestion, and absorption in filter-feeding bivalves. J Exp Mar Biol Ecol 91:77-92

Shumway SE, Newell RC, Crisp DJ, Cucci TL (1990) Particle selection in filter-feeding bivalve molluscs: a new technique on an old theme. In: Morton B (ed) The Bivalviaproceedings of a memorial symposium in honour of Sir Charles Maurice Yonge, Edinburgh, 1986. Hong Kong University Press, Hong Kong, p 151-165

Silverman H, Achberger EC, Lynn JW, Dietz RH (1995) Filtration and utilization of laboratory-cultured bacteria by Dreissena polymorpha, Corbicula fluminea, and Carunculina texasensis. Biol Bull 189:308-319

Silverman H, Lynn JW, Dietz TH (1996) Particle capture by the gills of Dreissena polymorpha: structure and function of latero-frontal cirri. Biol Bull 191:42-54

Silverman H, Lynn JW, Beninger PG, Dietz TH (1999) The role of latero-frontal cirri in particle capture by the gills of Mytilus edulis. Biol Bull 197:368-376

Soto D, Mena G (1999) Filter feeding by the freshwater mussel, Diplodon chilensis, as a biocontrol of salmon farming eutrophication. Aquaculture 171:65-81

Theisen BF (1982) Variation in size of gills, labial palp, and adductor muscle in Mytilus edulis L. (Bivalvia) from Danish waters. Ophelia 21(1):49-63

Utermöhl H (1958) Zur Vervollkommnung der quantitativen Phytoplankton-Methodik. Int Ver Theor Angew Limnol 9:1-38

Ward JE, Beninger PG, MacDonald BA, Thompson RJ (1991) Direct observations of feeding structures and mechanisms in bivalve molluscs using endoscopic examination and video image analysis. Mar Biol 111:287-291

Ward JE, MacDonald BA, Thompson RJ, Beninger PG (1993) Mechanisms of suspension feeding in bivalves: resolution of current controversies by means of endoscopy. Limnol Oceanogr 38(2):265-272

Ward JE, Newell RIE, Thompson RJ, MacDonald BA (1994) In vivo studies of suspension-feeding processes in the Eastern oyster, Crassostrea virginica (Gmelin). Biol Bull 186:221-240

Ward JE, Levinton JS, Shumway SE, Cucci T (1998) Particle sorting in bivalves: in vivo determination of the pallial organs of selection. Mar Biol 131:283-292

Wright RT, Coffin RB, Ersing CP, Pearson D (1982) Field and laboratory measurements of bivalve filtration of natural marine bacterioplankton. Limnol Oceanogr 27(1):91-98

Submitted: July 25, 2002; Accepted: December 5, 2002

Proofs received from author(s): February 28, 2003 